\title{
FAKTOR-FAKTOR YANG MEMPENGARUHI OMZET PENJUALAN UMKM KULINER PARTNER GOFOOD DI KOTA SOLO
}

\author{
Suprihatmi Sri Wardiningsih \\ Fakultas Ekonomi Universitas Slamet Riyadi Surakarta \\ bupri1960@gmail.com
}

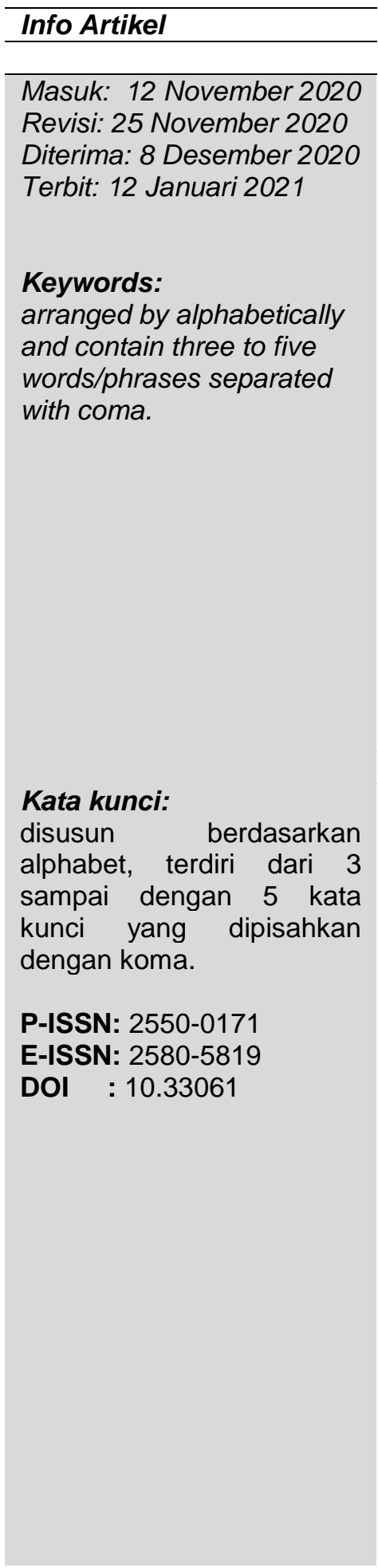

\begin{abstract}
This study aims to analyze the effect of operational working hours, number of orders, production costs, and promotion costs on sales turnover at GoFood culinary partners in Solo. This type of research will be carried out using quantitative descriptive methods. The population is all culinary MSMEs in Solo city who have utilized the GoFood application. Sample using 100 entrepreneurs, take of the purposive sampling technique. Sample criteria are entrepreneurs who have a business license and occupy a permanent place of business and not street vendors. The data source in this study is primary data that is data collected directly from respondents through questionnaire answers. The regression requirements test is performed through the Classical Assumptions test. Data analysis techniques using multiple linear regression analysis. Hypothesis testing is done by $t$ test using a significance level of 5\%. The results showed that operational working hours, number of orders, and production costs had a significant effect on sales turnover at GoFood partner culinary MSMEs in Solo while promotion costs had no significant effect on sales turnover.

Keywords: $\quad$ operational working hours, number of orders, production costs, promotion costs, sales turnover
\end{abstract}

\footnotetext{
Abstrak

Penelitian ini bertujuan untuk menganalisis pengaruh jam kerja operasional, jumlah pesanan, biaya produksi, dan biaya promosi terhadap omzet penjualan pada mitra kuliner GoFood di Solo. Jenis penelitian ini akan dilakukan dengan menggunakan metode deskriptif kuantitatif. Populasinya adalah seluruh UMKM kuliner di kota Solo yang telah memanfaatkan aplikasi GoFood. Sampel menggunakan 100 orang pengusaha, diambil dengan teknik purposive sampling. Kriteria sampel adalah pengusaha yang memiliki izin usaha dan menempati tempat usaha tetap dan bukan PKL. Sumber data dalam penelitian ini adalah data primer yaitu data yang dikumpulkan langsung dari responden melalui jawaban kuesioner. Uji persyaratan regresi dilakukan melalui uji Asumsi Klasik. Teknik analisis data menggunakan analisis regresi linier berganda. Pengujian hipotesis dilakukan dengan uji $t$ menggunakan taraf signifikansi $5 \%$. Hasil penelitian menunjukkan bahwa jam kerja operasional, jumlah pesanan, dan biaya produksi berpengaruh signifikan terhadap omzet penjualan pada UMKM kuliner mitra GoFood di Solo sedangkan biaya promosi tidak berpengaruh signifikan terhadap omzet penjualan.

Kata kunci: jam kerja operasional, jumlah pesanan, biaya produksi, biaya promosi, omzet penjualan
} 


\section{PENDAHULUAN}

Online food delivery service sebagai salah satu solusi alternatif dalam memenuhi kebutuhan konsumen. Aplikasi GoFood telah banyak dimanfaatkan oleh para pengusaha kuliner sebagai fitur layanan pengiriman pesanan makanan. Fitur GoFood,memberikan kemudahan bagi konsumen untuk memperoleh makanan dan minuman yang diinginkan dari berbagai pilihan restoran hanya melalui media smartphone tanpa harus mengunjungi toko makanan dan minuman tersebut.. Selain memberi kemudahan kepada konsumen, online food delivery service ini juga memberikan keuntungan bagi pelaku bisnis, membantu untuk memberikan akses yang selebar-lebarnya kepada mereka yang ingin berinovasi kuliner tanpa modal yang besar (Suryadi dan Ilyas, 2018). Dalam bisnis kuliner para pengusaha UMKM telah banyak yang menjalin kemitraan dengan perusahaan GoJek melalui fitur GoFood, aplikasi ini telah memberikan kontribusi positif pada peningkatan omzet penjualan dalam setiap harinya (Indraswari dan Kusuma, 2018).

Bisnis kuliner di kota Solo saat ini banyak memanfaatkan aplikasi Gofood, sehingga memberikan kontribusi bagi UMKM kuliner dalam meningkatkan omzet penjualan. Permasalahan yang terjadi bahwa pengusaha kuliner memiliki karakteristik yang beragam dalam mengelola bisnisnya sehingga turut mempengaruhi omzet penjualan. Faktor-faktor tersebut diantaranya jam kerja operasional, jumlah order, biaya produksi dan biaya promosi. Hal ini mendorong minat penelitian untuk menganalisis faktor-faktor yang mempengaruhi omzet penjualan UMKM kuliner partner GoFood di kota Solo.

Hasil penelitian Firdausa dan Arianti (2013) menunjukkan bahwa modal awal, lama usaha dan jam kerja berpengaruh positif dan signifikan terhadap terhadap pendapatan pedagang kios di Pasar Bintoro Demak. Hasil penelitian Indraswari dan Kusuma (2018) menunjukkan bahwa harga jual, jumlah order dan lama jam operasional berpengaruh positif dan signifikan terhadap pendapatan pengusaha rumah makan yang memanfaatkan aplikasi Go-Food di Kelurahan Sawojajar kota Malang. Hasil penelitian Fitalokasari (2017) menunjukkan bahwa curahan jam kerja, jumlah penumpang, dan biaya operasional berpengaruh positif dan signifikan terhadap pendapatan supir angkutan di kota Batu.

Berdasarkan latar belakang yang penulis kemukakan diatas, maka perumusan masalah dalam penelitian ini, apakah jam kerja operasional, jumlah order, biaya produksi, dan biaya promosi berpengaruh signifikan terhadap omzet penjualan pada UMKM kuliner partner GoFood di kota Solo. Penelitian ini bertujuan menganalisis signifikansi pengaruh jam kerja operasional, jumlah order, biaya produksi, dan biaya promosi terhadap omzet penjualan pada UMKM kuliner partner GoFood di kota Solo.

\section{METODE PENELITIAN}

Jenis penelitian yang akan dilaksanakan menggunakan metode deskripitif kuantitatif. Populasi adalah seluruh UMKM kuliner di kota Solo yang telah memanfaatkan aplikasi goFood. Pengambilan sampel menggunakan teknik purposive sampling. Kriteria sampel adalah pengusaha memiliki izin usaha dan menempati tempat usaha yang tetap (permanen) dan bukan PKL.

Teknik analisis data menggunakan analisis regresi linier berganda yang dinyatakn dengan persamaan sebagai berikut : 
Pengujian hipotesis dilakukan dengan uji t menggunakan tingkat signifikansi 5\%. Kriteria uji, jika $p$ value $<0,05$. Uji $\mathrm{F}$ bertujuan mengui ketepatan model dalam mempreduiksi pengaruh jam kerja operasional, jumlah order, biaya produksi, dan biaya promosi terhadap omzet penjualan. Uji koefisien determinasi bertujuan mengetahui persentase sumbangan pengaruh seluruh variabel independen terhadap variabel dependen.

\section{PEMBAHASAN}

Temuan ini menunjukkan bahwa jam kerja operasional berpengaruh signifikan terhadap omzet penjualan UMKM kuliner partner GoFood di kota Solo. Hasil regresi menunjukkan bahwa variabel jam kerja operasional memiliki koefisien regresi positif. Hasil ini menunjukkan bahwa semakin besar lama jam operasional akan mempengaruhi peningkatan omzet penjualan UMKM. Dengan demikian jam kerja operasional berpengaruh terhadap omzet penjualan UMKM. Jam kerja operasional dalam penelitian ini adalah lamanya waktu yang digunakan pengusaha kuliner mitra GoFood di kota Solo untuk memenuhi permintaan konsumen yang dihitung dalam satuan jam per minggu. Frekuensi lama jam operasional dapat mempengaruhi jumlah order, karena dengan semakin besar jam kerja yang dimanfaatkan akan berpotensi untuk menerima order yang lebih banyak sehingga omzet penjualan yang dicapai akan semakin besar. Dalam kenyataannya, pemanfaatan jam kerja operasional para mitra GoFood di kota Solo sangat beragam. Beberapa ada yang membuka usahanya mulai jam 9 pagi sampai dengan jam 5 sore, ada yang melayani konsumen hingga jam 9 malam. Jam kerja operasional tersebut rata-rata hanya memanfaatkan 6 hari dalam seminggu, namun ada yang membuka usahanya 7 hari dalam seminggu penuh. Dengan demikian lama jam operasional akan turut mempengaruhi pencapaian omzet penjualan UMKM.

Temuan ini menunjukkan bahwa jumlah order berpengaruh signifikan terhadap omzet penjualan UMKM kuliner partner GoFood di kota Solo. Hasil regresi menunjukkan bahwa variabel jumlah order memiliki koefisien regresi positif. Hasil ini menunjukkan bahwa semakin besar jumlah order akan mempengaruhi peningkatan omzet penjualan UMKM.

Temuan ini menunjukkan bahwa biaya produksi berpengaruh signifikan terhadap omzet penjualan UMKM kuliner partner GoFood di kota Solo. Hasil regresi menunjukkan bahwa variabel biaya produksi memiliki koefisien regresi positif. Hasil ini menunjukkan bahwa semakin besar biaya produksi berarti semakin besar aktivitas perusahaan untuk memenuhi permintaan pelanggan sehingga omzet penjualan yang akan dicapai juga akan semakin besar. Biaya produksi yang dkeluarkan usaha kuliner mitra GoFood dalam penelitian ini ditentukan dari besarnya biaya-biaya yang dikeluarkan untuk membeli bahan baku, membayar upah tenaga kerja, dan pengeluaran overhead pabrik. Dengan demikian peningkatan biaya produksi berpengaruh terhadap peningkatan omzet penjualan.

Temuan ini menunjukkan bahwa biaya promosi tidak berpengaruh signifikan terhadap omzet penjualan UMKM kuliner partner GoFood di kota Solo. Hasil regresi menunjukkan bahwa variabel biaya promosi memiliki koefisien regresi positif. Hasil ini menunjukkan bahwa semakin besar biaya promosi berarti tujuan perusahaan untuk meningkatkan permintaan konsumen akan semakin besar sehingga berkontribusi pada peningkatan omzet penjualan. Namun secara statistik, pengaruh kedua variabel ini tidak signifikan. Hal ini dapat disebabkan karena pengusaha kuliner yang menjadi mitra GoFood di kota Solo semuanya melakukan promosi yang gencar sehingga terjadi persaingan yang ketat. Faktor lain, permintaan konsumen terhadap produk kuliner tidak hanya ditentukan oleh promosi melainkan dapat ditentuan oleh faktor kualitas produk, kualitas layanan pengusaha kuliner, 
harga produk, dan faktor lokasi usaha kuliner. Dengan demikian besarnya biaya promosi yang dikeluarkan oleh pengusaha kuliner tidak akan mempengaruhi omzet penjualan.

\section{KESIMPULAN}

Berdasarkan hasil pengujian setiap hipotesis, diperoleh kesimpulan (1) Jam kerja operasional berpengaruh signifikan terhadap omzet penjualan, berarti $\mathrm{H} 1$ diterima. (2) Jumlah order berpengaruh signifikan terhadap omzet penjualan, berarti $\mathrm{H} 2$ diterima. (3) Biaya produksi berpengaruh signifikan terhadap omzet penjualan, berarti H3 diterima. (4) Biaya promosi tidak berpengaruh signifikan terhadap omzet penjualan, berarti H4 diterima. Pengusaha kuliner partner GoFood di Kota Solo diharapkan untuk meningkatkan jam kerja operasional dan menambah kapasitas produksi sehingga dapat meningkatkan jumlah pesanan yang selanjutnya berkontribusi pada peningkatan omzet penjualan.

Untuk lebih mengoptimalkan omzet penjualan, UMKM kuliner partner GoFood di Kota Solo diharapkan untuk melakukan pengelolaan keuangan yang efektif dan efisien terhadap semua aktivitas produksi dan penjualan. Bagi penelitian selanjutnya sangat diharapkan untuk meneliti faktor-faktor lain yang mempengaruhi omzet penjualan UMKM kuliner partner GoFood dan dapat bahkan dapat melakukan analisis perbandingan kinerja keuangan antara UMKM kuliner partner GoFood dengan UMKM kuliner partner GrabFood. 


\section{DAFTAR PUSTAKA}

Firdausa, R.A. dan Arianti, F., 2013, “Pengaruh Modal Awal, Lama Usaha dan Jam Kerja Terhadap Pendapatan Pedagang Kios Di Pasar Bintoro Demak", Diponegoro Journal Of Economics, Vol. 2 (1), Hal. 1-6.

Fitalokasari, M., 2017, “Pengaruh Curahan Jam Kerja, Jumlah Penumpang, Jumlah Tanggungan Keluarga dan Biaya Operasional Terhadap Pendapatan Supir Angkutan Umum di Kota Batu", Jurnal Ekonomi Pembangunan, Vol. 5 (1), Hal. 38-75.

Indraswari, A. dan Kusuma, H., 2018, “Analisa Pemanfaatan Aplikasi Go-Food Bagi Pendapatan Pemilik Usaha Rumah Makan Di Kelurahan Sawojajar Kota Malang", Jurnal Ilmu Ekonomi, Vol .2 (1), Hal. 63-73.

Prapti, L. dan Rahoyo, 2018, "Dampak Bisnis Kuliner Melalui Gofood Bagi Pertumbuhan Ekonomi di Kota Semarang", Dinamika Sosial Budaya, Vol. 20 92), Hal. 120-133.

Suryadi, D.F., dan Ilyas, M.I.F., 2018, "Adopsi Online Food Delivery Service Bagi Wirausaha Pemula di Kota Makassar (Studi Kasus Pada Big Bananas)", Prosiding Seminar Hasil Penelitian (SNP2M) 2018, Hal. pp.75-80. 